bable Franklin, made it a congenial custom to lunch together at the Strand Palace Hotel of a Saturday.

What must assuredly have soured her life at King's and, more importantly, her relations with Wilkins, was the written guarantee that J.T. Randall, the director of the laboratory (not, by the way, a "Scottish physicist", as Judson has him), had given her that the DNA problem would be hers alone and that Wilkins would be pursuing other interests; meanwhile, Randall had given Wilkins to understand that the new recruit would assist him in the crystallography ofDNA. The mischief that this caused cannot be doubted, but neither can Franklin's unaccommodating character and hostility towards the colleague with whom she should have shared her ideas.

When I came to the laboratory at King's, Franklin was already dead, but she was not remembered with affection. Before a laboratory seminar on DNA, she circulated, as Judson relates, black-edged cards, announcing the demise of the helix and concluding: "It is hoped that Dr M. H. F. Wilkins will speak in memory of the late helix." A witness of these events told me that when Franklin discovered an error in a calculation of a Patterson function, which had apparently misled her, she begged him not to tell Wilkins. Franklin's statue as a scientist remains unchallenged, but Judson takes the view that attempts at canonization have done a disservice to her memory.

Chargaff is another whose work on DNA has sometimes been seen as undervalued. He was one of a brilliant and cantankerous galère of Central Europeans given shelter by Columbia University in the late 1930s. Grateful or not, they found it difficult to conceal their scorn for their American colleagues, who spoke no Latin or Greek, and they detested the insidious incursion of the 'hard sell' into science.

Chargaff, moreover, could no more retain a wounding witticism in his mouth than a hot potato. To be sure, his description of Crick as "a fading racing tout" and something out of Hogarth departs from the norms of polite academic discourse, and Judson properly describes it as embarrassing. The Watson and Crick of 1952 were neither of them exactly Chargaff's type. Wilkins, by contrast, remembers him as nothing other than kind and helpful. It is certain only that, had Chargaff merely kept his mouth shut, instead of denouncing Watson and Crick and their hateful model, his place in the pantheon would have been a deal more secure. One might mention in this regard the late Lord Todd, a man of impregnable selfesteem, who was irked by talk of Watson and Crick's structure. They had not, he would declare, determined the structure of DNA; he, Todd, had determined its structure, they only its conformation.

Judson's book and Watson's have been reissued, not perhaps for the last time, as classics. The Double Helix appears with the original foreword of saintly forbearance by Sir Lawrence Bragg, and a new introduction by Steve Jones which reveals that even the most accomplished of performers can have an off-day.

A historian has mused that the memory of man is too frail a thread on which to hang history; Judson's achievement, in drawing out the memories of so many participants in the epic of molecular biology and weaving them into a single robust skein, is magisterial. His work fittingly commemorates a golden age which already seems as remote as that of Darwin and Huxley.

Walter Gratzer is at The Randall Institute, King's College, London, 26-29 Drury Lane, London WC2B 5RL, UK.

\section{The solution to pollution?}

\section{Laboratory Earth: The Planetary Gamble We Can't Afford To Lose} by Stephen Schneider

Basic Books: 1997. Pp.174. \$20. Weidenfeld

\& Nicholson $£ 11.99$

\section{John Houghton}

Humans have rarely anticipated environmental pollution; action and pollution control have generally followed on from environmental disasters or unacceptable pollution damage. However, the potential magnitude of damage to the environment that humans are now able to cause, and the speed with which such damage can occur, are such that it is now necessary for the impact to be assessed and action taken before the damage occurs rather than afterwards. This is particularly true with pollution that is global in its extent, such as that leading to climate change as a result of the increased burning of fossil fuels or tropical deforestation.

Because of this need to anticipate, questions are bound to be asked about the accuracy of scientific arguments, and the extent to which the increased pollution is likely to matter. Answers can be found only by viewing the problem in a wide context, taking account of both the science and the politics of the problem. The science of climate change is highly interdisciplinary, involving all of the main disciplines of natural and social science. Because few can claim expertise in more than a small number of the appropriate disciplines, any adequate assessment of the problem necessarily involves a large community of scientists.

It is in this wide context of science and policy that Stephen Schneider addresses the issue of global warming and climate change. The likely changes projected by climate models are compared with changes that have occurred over the millions of years of the
Earth's climatic history; the modelling of these past changes has helped to validate the climate models used for future projections.

In presenting the effects of likely climate change, Schneider does not focus on the impact on the resources required by humans, such as water resources; a more balanced account would have given these critical effects on humans more attention. Rather, he homes in strongly on the loss of biodiversity, devoting a whole chapter to it - despite the large uncertainties that tend to fog the issue - arguing that, because biodiversity is fundamentally irreplaceable, its loss must be considered as the most serious effect of rapid climate change.

The latter part of the book is devoted to the question of how policy decisions should be approached in such a complex field. Here the book has a distinctive North American flavour; there has been much more of an open battle in the United States between some of the scientists and the lobbyists working for the energy industries. This in turn has stimulated a lively debate between ecologists, who are trying to preserve the planet, industrialists, who think any problem can be fixed post hoc, and economists, who are trying to gauge the likely effect on the sacred cow of economic growth.

For logical decision-making, integrated assessment' sounds an appropriate formula, but is it realistic to suppose that all the relevant factors can be weighed by any of our existing technical machinery? Of course, cost-benefit analysis can be attempted, but the things that we really value are hard if not impossible to turn into numbers, especially numbers representing money. Schneider emphasizes the value of going through the discipline and arguments that might lead to integrated assessment', but sensibly draws back from presenting it as the final arbiter. In what will be for many readers the most interesting part of the book, he attempts to explain the much more complex relationship between policy judgements and the scientific, technological and economic arguments (with all their uncertainties) that assist in the formulation of policy and the prescription of action.

Schneider has done much to raise awareness of global environmental issues, particularly through his contributions to the media. He speaks fast and lucidly, and his writing possesses much of the same racy style. The book is laced with considerable technical detail that is informative to those with a training in science or policy, but even readers who are not scientifically trained will gain a broad understanding of the scope and scale of one of the most important environmental challenges of our day.

Sir John Houghton is chairman of the

Royal Commission on Environmental Pollution,

Church House, Great Smith Street,

London SWIP 3BZ, UK. 